\title{
Further studies on the nutritional factors affecting the urinary excretion of acid-soluble peptides in rats
}

\author{
BY TADASHI NOGUCHI, TAEK JEONG NAM, HISANORI KATO \\ AND HIROSHI NAITO \\ Department of Agricultural Chemistry, Faculty of Agriculture, The University of Tokyo, \\ Bunkyo-ku, Tokyo 113, Japan
}

(Received 21 July $1987-$-Accepted 4 May 1988)

\begin{abstract}
1. Nutritional factors affecting the urinary excretion of acid-soluble peptides (ASP) were studied in rats. The ratio, total urinary nitrogen:ASP-form leucine + valine was lowest in the rats fed on a protein-free diet and increased as retained $\mathrm{N}$ :absorbed $\mathrm{N}$ decreased. The ratio was not affected by dietary protein level when the level was below the National Research Council (1978) recommended requirement, but increased greatly when it exceeded the recommended requirement.

2. The excretion of ASP-form leucine + valine per $\mathrm{kg}$ body-weight was significantly lower in the proteindeficient rats than in those fed on protein-adequate diets. This variable decreased during the stage of rapid growth, but did not change as markedly after the onset of adolescence. It increased again when the rats became older. The patterns of change in the rate of excretion of ASP-form amino acids during growth and that of $N^{\top}$-methylhistidine were different.

3. When labelled amino acids were injected into rats, the largest amount of the ASP-form label was excreted on the 1st day of injection. From the 2nd day the excretion of ASP-form label decreased exponentially.

4. The findings suggest that the rate of urinary excretion of ASP-form amino acids can be employed as an index of protein metabolism, particularly as a simple index of the assessment of the status of protein nutrition.
\end{abstract}

Human beings and domestic animals excrete many kinds of peptides in the urine (Hanson \& Fittkau, 1958; Ansorge et al. 1961; Skarzynski \& Sarnecka-Keller, 1962; Meilman et al. 1963; Waley, 1966; Ansorge \& Hanson, 1967; Hanson \& Ansorge, 1967; Prockop \& Kivirikko, 1967; Takita et al. 1974; Askenasi, 1975; Asatoor et al. 1976; Matsuki et al. 1976; Szymanowicz et al. 1979; Adams \& Frank, 1980; Takahashi et al. 1987). Ansorge \& Hanson (1967) identified human urinary peptides and showed that quantitatively a large proportion of the peptides are proline- or hydroxyproline-containing peptides. From those observations, they concluded that urinary peptides are composed mainly of the degradation products of collagen.

In spite of these extensive studies to elucidate the chemical structure of urinary peptides, less effort has been made to elucidate the dietary or physiological factors affecting the urinary excretion of peptides. Prockop \& Kivirikko (1967) reported that urinary excretion of proline-containing peptides increases when the degradation of collagen is presumed to increase, i.e. in Paget disease. Asatoor et al. (1976) also showed an increase in urinary peptides in Wilson's disease. These results suggested that the urinary excretion of peptides reflects some physiological or nutritional events in the body, especially the degradative state of body proteins, as pointed out by Skarzynski \& Sarnecka-Keller (1962).

In our previous paper (Noguchi et al. 1982), we showed that the rate of urinary excretion of acid-soluble peptides (ASP) in protein-depleted women and rats is proportional to their metabolic body size. Furthermore, the rate of excretion of urinary ASP in protein-fed rats was greater than that in protein-depleted rats. However, the amino acid pattern of the total urinary ASP was little affected by dietary proteins, suggesting that urinary ASP are endogenous products. These results suggested to us that extensive studies on the rate of urinary excretion of ASP may lead to the discovery of a new index of protein metabolism in the body. The present work is a study of the effects of the quantity and quality of dietary 
proteins on the urinary excretion of ASP in relation to the excretion of total nitrogen and $N^{\tau}$-methylhistidine, the effect of growth stage on the excretion of ASP, and the mode of excretion of labelled ASP after injection of labelled amino acids.

\section{MATERIALS AND METHODS \\ Animals and materials}

Male Wistar rats were purchased from Shizuoka Agricultural Cooperative for Laboratory Animals (Hamamatsu) and raised in wire-bottomed cages in a room kept at $22^{\circ}$. The diets and water were available ad lib.

Casein, $\beta$-maize starch, mineral and vitamin mixtures were obtained from the Oriental Yeast Co. (Tokyo). Vitamin and mineral mixtures were prepared according to Rogers \& Harper (1965). Wheat gluten was obtained from Nakarai Chemicals (Kyoto) and isolated soya-bean protein (Fujipro R) from Fuji Seiyu Co. (Osaka). Concentrated rice protein was prepared from an $\alpha$-amylase $(E C 3.2 .1 .1)$ digest of polished rice. $\mathrm{L}-\left[\mathrm{U}-{ }^{14} \mathrm{C}\right]$ proline and L- $\left[3,4(n)-{ }^{3} \mathrm{H}\right]$ valine were purchased from Amersham International plc, Amersham, Bucks.

\section{Experimental diets}

The experimental diets contained $(\mathrm{g} / \mathrm{kg})$ : soya-bean oil 50 , cellulose powder 50 , mineral mixture 40 , vitamin mixture 10 . Protein sources are described above. $\beta$-Maize starch was used to adjust the total amount to $1 \mathrm{~kg}$. In Expt 1, the protein sources were included at $120 \mathrm{~g}$ crude protein $(\mathrm{N} \times 6 \cdot 25) / \mathrm{kg}$. A protein-free diet was also prepared. When the gluten diet was supplemented with lysine monohydrochloride $(5 \mathrm{~g} / \mathrm{kg}$ diet $)$ and threonine $(3 \mathrm{~g} / \mathrm{kg}$ diet), starch was replaced by these amino acids. In Expt 2, casein diets containing 0, 60, 120, 180 and $240 \mathrm{~g}$ casein $/ \mathrm{kg}$ diet were prepared. In Expt 3, amino acids were employed as $\mathrm{N}$ sources, as will be described later (p. 323). In Expt 4, casein diets containing 120 and $240 \mathrm{~g}$ casein $/ \mathrm{kg}$ diet were supplemented with L-methionine at 2 and $4 \mathrm{~g} / \mathrm{kg}$ diet respectively. In Expt 5, the casein diet with $120 \mathrm{~g}$ casein $/ \mathrm{kg}$ diet was used.

The crude protein content of the concentrated rice protein was $550 \mathrm{~g} / \mathrm{kg}$ and that of the isolated soya-bean protein was $920 \mathrm{~g} / \mathrm{kg}$, as determined by the Kjeldahl method. Crude protein contents of gluten and casein were 850 and $930 \mathrm{~g} / \mathrm{kg}$ respectively.

\section{Expt 1. Effects of dietary proteins on the urinary excretion of ASP}

Rats of mean initial body-weight $105 \mathrm{~g}$ (five rats for each dietary group) were fed on the diet containing $120 \mathrm{~g}$ casein $/ \mathrm{kg}$ diet for 1 week. Then the rats were fed on diets containing different proteins or the protein-free diet for a further $7 \mathrm{~d}$. Urine and faeces were collected for the last $2 \mathrm{~d}$ and retained for chemical analyses. The final body-weights ( $\mathrm{g}$ ) of the animals were: 136 (SE 3), 110 (SE 1), 130 (SE 1), 130 (SE 1), 125 (SE 3), 95 (SE 1) for the casein, gluten, gluten supplemented with lysine and threonine, soya-bean protein, rice protein, and protein-free diet groups respectively.

\section{Expt 2. Effect of dietary protein level on the urinary excretion of ASP}

The initial body-weight of the rats was $190 \mathrm{~g}$. They were fed on the diets containing 0,60 , 120,180 or $240 \mathrm{~g}$ casein $/ \mathrm{kg}$ diet for $7 \mathrm{~d}$ (five rats for each group), and urine and faeces were collected for the last $2 \mathrm{~d}$. The final body-weights (g) of the rats were: 181 (SE 6), 190 (SE 6), 212 (SE 12), 220 (SE 3) and 220 (SE 1) for the rats fed on 0, 60, 120, 180 and $240 \mathrm{~g}$ casein $/ \mathrm{kg}$ diet respectively. 


\section{Expt 3. Effect of a lysine- or tryptophan-deficient amino acid mixture on the urinary excretion of $A S P$}

Male Wistar rats of body-weight $160 \mathrm{~g}$ were divided into six groups of five each. The first group was fed on the amino acid mixture prepared according to the National Research Council (1978). Glutamic acid was supplied to give a total amino acid level in the diet of $120 \mathrm{~g} / \mathrm{kg}$ (as crude protein). This diet will be referred to as the control amino acid diet. The second group received a lysine-deficient diet which was prepared by replacing lysine in the control amino acid diet by maize starch. The third group was fed on a diet which contained twice the lysine content of the control diet, achieved by replacing part of the maize starch by lysine monohydrochloride. The fourth group was fed on a tryptophan-deficient diet and the fifth group on a diet with twice the tryptophan content of the control amino acid diet. The last group received a diet containing twice the level of all amino acids in the control diet. These amino acid diets were given for 1 week and urine samples were collected for $2 \mathrm{~d}$ at the end of the period. N and ASP in the urine were analysed and the results are expressed as the ratio, N:ASP-form amino acids. The final body-weights $(\mathrm{g})$ of the animals were: 188 (SE 5), 150 (SE 2), 193 (SE 8), 156 (SE 2), 196 (SE 8) and 199 (SE 2) for the rats fed on the control amino acid diet, tryptophan-deficient, tryptophan-excess, lysine-deficient, lysine-excess and twice the control amino acid level diets respectively.

\section{Expt 4. Changes in the urinary excretion of ASP during growth in rats fed at two levels of dietary casein}

Five 5-week-old rats of $110 \mathrm{~g}$ initial body-weight were fed on the diet containing casein at $120 \mathrm{~g} / \mathrm{kg}$ diet and the other five rats on the $240 \mathrm{~g}$ casein $/ \mathrm{kg}$ diet, for almost 2 years. On eight occasions during this period (the time intervals are indicated in Figs. 6 (p. 331) and 7 (p. 332)), urine was collected for $48 \mathrm{~h}$ and the amount of ASP in the urine was analysed.

\section{Expt 5. Excretion of labelled ASP after injection of labelled amino acids}

Five male Wistar rats of $100 \mathrm{~g}$ initial body-weight were fed on the casein diet ( $120 \mathrm{~g}$ casein/ $\mathrm{kg}$ diet) $a d$ lib. for 1 week. At this stage, the mean body-weight of the animals was 127 (SE 3) g. They were maintained on the casein diet and were injected with a mixture of 100 $\mu \mathrm{Ci} \mathrm{L}-\left[3,4(n)-{ }^{3} \mathrm{H}\right]$ valine $(25 \mathrm{Ci} / \mathrm{mmol})$ and $10 \mu \mathrm{Ci} \mathrm{L}-\left[\mathrm{U}-{ }^{14} \mathrm{C}\right]$ proline $(290 \mathrm{mCi} / \mathrm{mmol})$ intraperitoneally. Urine samples $(24 \mathrm{~h})$ were collected daily for the following $9 \mathrm{~d}$. On the last day, the mean body-weight of the rats was 164 (SE 5) g. The urine samples were collected daily in $10 \mathrm{ml}$ sulphosalicylic acid solution $(100 \mathrm{~g} / \mathrm{l})$ and after the collection period $(24 \mathrm{~h})$ the total volume was adjusted to $50 \mathrm{ml}$ with deionized water. A portion of the filtered urine samples $(30 \mathrm{ml})$ was desalted with Dowex $50 \mathrm{~W} \times 4$ (H-form) as described previously (Noguchi et al. 1982). The desalted samples were dried by rotary evaporation and the dried samples were dissolved in $5 \mathrm{ml}$ deionized water. ASP were separated from free amino acids by chromatography using a copper-Sephadex column as described previously (Noguchi et al. 1982).

The ASP fraction (fraction A of Noguchi et al. (1982)) was desalted again as described previously and the desalted, dried ASP were dissolved in $5 \mathrm{ml}$ deionized water. A $0.5 \mathrm{ml}$ portion of each sample was mixed with $10 \mathrm{ml}$ toluene-based liquid-scintillation cocktail (Kawakami \& Shimura, 1974) and the radioactivity was determined for ${ }^{3} \mathrm{H}$ and ${ }^{14} \mathrm{C}$ using an Aloka liquid-scintillation counter (Aloka, Tokyo). The free amino acid fraction from $\mathrm{Cu}$-Sephadex chromatography (fraction C of Noguchi et al. (1982)) was also desalted as described for the preparation of the ASP fraction and the radioactivity in this free amino acid fraction was determined. 


\begin{abstract}
Analyses
Urine was collected for $2 \mathrm{~d}$ in $10 \mathrm{ml}$ sulphosalicylic acid solution $(100 \mathrm{~g} / 1)$. A portion of the collected urine was retained for $\mathrm{N}$ determination. A $5 \mathrm{ml}$ portion of the urine was diluted to give a final concentration of sulphosalicylic acid of $20 \mathrm{~g} / \mathrm{l}$. The precipitate was filtered through Whatman no. 44 filter paper and a portion of the filtrate (usually $5 \mathrm{ml}$ ) was desalted employing a Dowex $50 \mathrm{~W} \times 4$ column $(26 \times 200 \mathrm{~mm}, \mathrm{H}$ form $)$. The samples thus obtained were dissolved in $5 \mathrm{ml}$ deionized water. To $400 \mu \mathrm{l}$ of this sample was added $20 \mu 11 \mathrm{M}$-hydrochloric acid and the sample filtered through a $0 \cdot 2 \mu \mathrm{m}$ filter (SJHVO4NS; Nihon Millipore. Kogyo Co., Yonezawa). The amino acid composition in the samples was determined using a Hitachi 835-50 amino acid analyser with a lithium-type column $(2.6 \times 250 \mathrm{~mm})$. From the results of this analysis, the free amino acid content of urine was obtained. The total amino acid content of urine samples was determined after hydrolysis of the desalted urine for $24 \mathrm{~h}$ at $105^{\circ}$ with $6 \mathrm{M}-\mathrm{HCl}$. The difference between the total and the free amino acids was the amount of ASP-form amino acids. The total $N^{\top}$-methylhistidine excretion was also obtained from the total amino acid analysis.

$\mathrm{N}$ in feeds, faeces and urine was determined by the micro-Kjeldahl method.

To calculate the efficiency of dietary protein- $\mathrm{N}$ retention, the endogenous urinary $\mathrm{N}$ was assumed to be
\end{abstract}

urinary $\mathrm{N}$ of the rats fed on protein-free diet $\times \frac{\text { mean body-wt of protein-diet-fed rats }}{\text { mean body-wt of protein-free-diet-fed rats }}$.

Metabolic faecal $\mathrm{N}$ was also presumed to be proportional to the mean body-weight for the protein-diet-fed rats and the protein-free-diet-fed rats, because there was no significant difference in the ratio, faecal $\mathrm{N}(\mathrm{mg})$ : body-weight $(\mathrm{kg})$ between the two groups of rats fed on the protein-free diet in Expts 1 and 2 (mean 99 (SE 5), mean 90 (SE 5) mg N/kg bodyweight respectively).

\title{
RESULTS
}

Relation between the urinary excretion of ASP-form amino acids and the total amino acids

The regression factors ( $Y=a X+b$, SD from regression) are shown in Table 1 , where $Y$ is the daily excretion of the total acid-soluble amino acids $(\mu \mathrm{mol} / \mathrm{d})$ and $X$ is that of ASPform amino acids $(\mu \mathrm{mol} / \mathrm{d})$. Amino acids not shown in Table 1 were omitted because the recovery during acid hydrolysis was questionable in the cases of tyrosine and methionine and some unknown compounds hindered the determination of free aspartic acid. The results show that almost all the acid-soluble amino acids are excreted as ASP-form amino acids. However, variable amounts of free glutamine or glutamic acid were excreted although the excretion of ASP-form glutamine or glutamic acid correlated with that of the other ASP-form amino acids.

In the following experiments we have used leucine and valine as representative amino acids when discussing the results. However, any amino acid except proline, hydroxyproline and glycine could be used to represent the ASP-form amino acids; the reasons for omitting these three amino acids will be discussed later (pp. 325-326). Another reason for using valine and leucine was that the values for leucine, isoleucine, valine and histidine deviated relatively little from the regression (Table 1). 
Table 1. Variables of the linear regression between the urinary excretion of the total and acid-soluble peptide (ASP)-form amino acids in each amino acid

(All the values in Expts 1 and 2 with values for three extra rats in Expt 1 (two fed on the protein-free diet and one fed on the casein diet) were used to calculate the values shown. The rate of excretion of the total and ASP-form amino acids was fitted to the linear regression $(Y=a X+b$, where $Y$ is the rate of excretion of the total amino acid $(\mu \mathrm{mol} / \mathrm{d})$ and $X$ is the rate of excretion of ASP-form amino acid $(\mu \mathrm{mol} / \mathrm{d})))$

\begin{tabular}{|c|c|c|c|c|c|c|}
\hline \multirow[b]{2}{*}{ Amino acid } & \multicolumn{4}{|c|}{$\begin{array}{l}\text { Coefficients of } \\
\text { regression* }\end{array}$} & \multirow[b]{2}{*}{$r$} & \multirow[b]{2}{*}{$X$-range $\dagger$} \\
\hline & $a$ & SDRC & $b$ & SD & & \\
\hline Threonine & 1.4 & $0 \cdot 22$ & $0 \cdot 8$ & $1 \cdot 34$ & $0 \cdot 928$ & $0 \cdot 44-3 \cdot 52$ \\
\hline Serine & $1 \cdot 2$ & 0.05 & $0-5$ & $0 \cdot 25$ & 0.990 & $0 \cdot 30-3 \cdot 40$ \\
\hline Glutamine/glutamic acid & $2 \cdot 6$ & 0.60 & 0.9 & $10 \cdot 23$ & 0.778 & $1.58-11.62$ \\
\hline Glycine & $1 \cdot 1$ & 0.01 & $0 \cdot 9$ & 0.55 & 0.999 & $2 \cdot 87-30 \cdot 59$ \\
\hline Proline & $1 \cdot 1$ & 0.01 & $0 \cdot 0$ & $0 \cdot 18$ & 0.999 & $1 \cdot 89-10 \cdot 65$ \\
\hline Alanine & $1 \cdot 3$ & 0.05 & 0.5 & $0 \cdot 37$ & 0.993 & $0.55-4.66$ \\
\hline Valine & $1 \cdot 3$ & 0.02 & $-0 \cdot 1$ & 0.08 & 0.999 & $0 \cdot 34-2 \cdot 49$ \\
\hline Isoleucine & $1 \cdot 2$ & 0.01 & $0 \cdot 0$ & 0.03 & 0.999 & $0.15-1.52$ \\
\hline Leucine & $1 \cdot 2$ & 0.03 & $0 \cdot 0$ & $0 \cdot 09$ & 0.998 & $0.25-2.06$ \\
\hline Phenylalanine & $1 \cdot 2$ & 0.03 & $0 \cdot 2$ & $0 \cdot 11$ & 0.994 & $0 \cdot 13-2 \cdot 31$ \\
\hline Lysine & 1.5 & 0.03 & -0.1 & 0.26 & 0.997 & $0 \cdot 45-4 \cdot 46$ \\
\hline Histidine & $1 \cdot 2$ & 0.02 & $0 \cdot 1$ & 0.08 & 0.998 & $0.20-1.98$ \\
\hline Arginine & $1 \cdot 1$ & 0.02 & 0.1 & 0.07 & 0.999 & $0 \cdot 30-2 \cdot 56$ \\
\hline
\end{tabular}

So, standard deviation from the regression (n 58); SDRC, standard deviation of the regression coefficient.

* The regression was statistically significant $(P<0.001)$ for all amino acids including glutamine/glutamic acid.

$\dagger$ Expressed as $\mu \mathrm{mol} / \mathrm{d}$.

\section{Excretion of ASP-form amino acids}

Fig. 1 illustrates a comparison of the urinary ASP-form amino acid excretion patterns of rats fed on the control protein (casein)-containing diet and that of rats fed on the proteinfree diet. The amino acid patterns of urinary ASP for both groups of rats were very similar. These results were in accordance with our previous findings (Noguchi et al. 1982), although the method of ASP analysis was different. This was also true in the case of other dietary proteins (values not shown).

Almost all the ASP-form amino acid levels $(\mu \mathrm{mol} / \mathrm{kg}$ body-weight or $\mu \mathrm{mol} / \mathrm{kg}$ bodyweight ${ }^{0.75}$ ) decreased, maintaining an unchanged amino acid pattern as the rats grew older (values not shown). This finding suggested that the amino acid pattern of ASP did not change significantly during growth and adolescence. However, the decrease in ASP-form proline, hydroxyproline and glycine was more rapid than that of the other amino acids, especially when the rats were fed on $240 \mathrm{~g}$ casein $/ \mathrm{kg}$ diet (Figs. 6 (p. 331) and 7 (p. 332); only the values of proline are shown in Fig. 7, but the changes in the values of hydroxyproline and glycine were similar to the change in the values of proline); that is, rats of approximately $120 \mathrm{~g}$ body-weight excreted relatively larger amounts of ASP-form proline, hydroxyproline and glycine compared with those of the older rats. The ratio of the daily excretion of ASP-form leucine + valine on the $120 \mathrm{~g}$ casein $/ \mathrm{kg}$ diet during the first period (body-weight approximately $120 \mathrm{~g}$ ) to that for the fourth period (body-weight approximately $380 \mathrm{~g}$ ) was 2.78 (SE 0.23 ); the corresponding value for ASP-form proline was 5.17 (SE 0.68). A similar trend was observed for the $240 \mathrm{~g}$ casein $/ \mathrm{kg}$ diet (values 3.34 (SE 0.31) and 8.76 (SE 0.78) for ASP-form leucine + valine and ASP-form proline respectively). These 


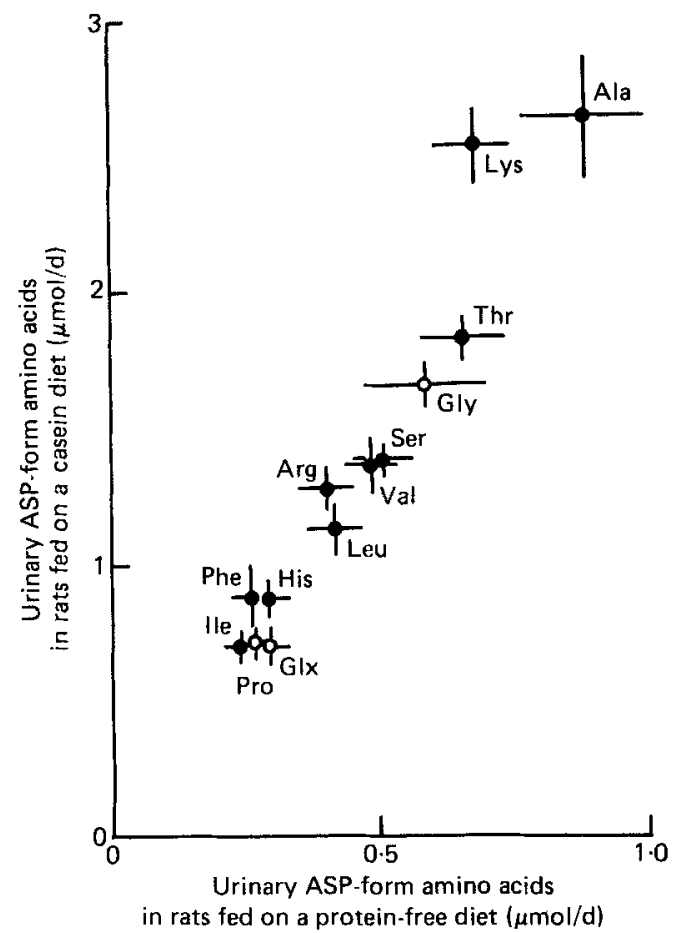

Fig. 1. Expt 1. The amino acid pattern of urinary acid-soluble peptides (ASP) from rats fed on a $120 \mathrm{~g}$ casein $/ \mathrm{kg}$ diet compared with that of rats fed on a protein-free diet. Values are means with their standard errors for five rats for each group. Vertical lines represent the standard errors of the means for the rats fed on the casein diet and horizontal lines those for the rats fed on a protein-free diet. (O), Values are reduced to a scale of one-tenth the actual size. Ala, alanine; Lys, lysine; Thr, threonine; Gly, glycine; Ser, serine; Val, valine; Arg, arginine; Leu, leucine; His, histidine; Phe, phenylalanine; Glx, glutamine/ glutamic acid; Pro, proline; Ile, isoleucine.

results suggest that the origin of ASP-form proline, hydroxyproline and glycine is different, at least in part, from that of the other amino acids and implies that the excretion of ASPform proline, hydroxyproline and glycine has a different metabolic significance from that of the other ASP-form amino acids. We have, therefore, assumed that there is sufficient indication that the excretion of ASP-form leucine + valine reffects the status of whole body protein degradation, including the contribution from collagen degradation. (When whole body protein synthesis or degradation is discussed, collagen synthesis is also taken into account.) On the other hand, ASP-form proline, hydroxyproline and glycine mainly reflect the rate of collagen degradation, as presumed by many investigators (e.g. Ansorge \& Hanson, 1967). If our assumption is true, the decrease in the rate of collagen degradation on a unit body-weight basis during growth is faster than the decrease in the rate of whole body protein degradation (including collagen degradation), especially in the rats fed on a $240 \mathrm{~g}$ casein $/ \mathrm{kg}$ diet.

\section{Expt 1}

Fig. 2 shows the rate of urinary excretion of ASP in the rats fed on various protein sources. The excretion rate of ASP per kg body-weight was lower in the rats fed on the protein-free diet than that of the five groups of rats fed on various protein diets $(P<0.05)$. However, 


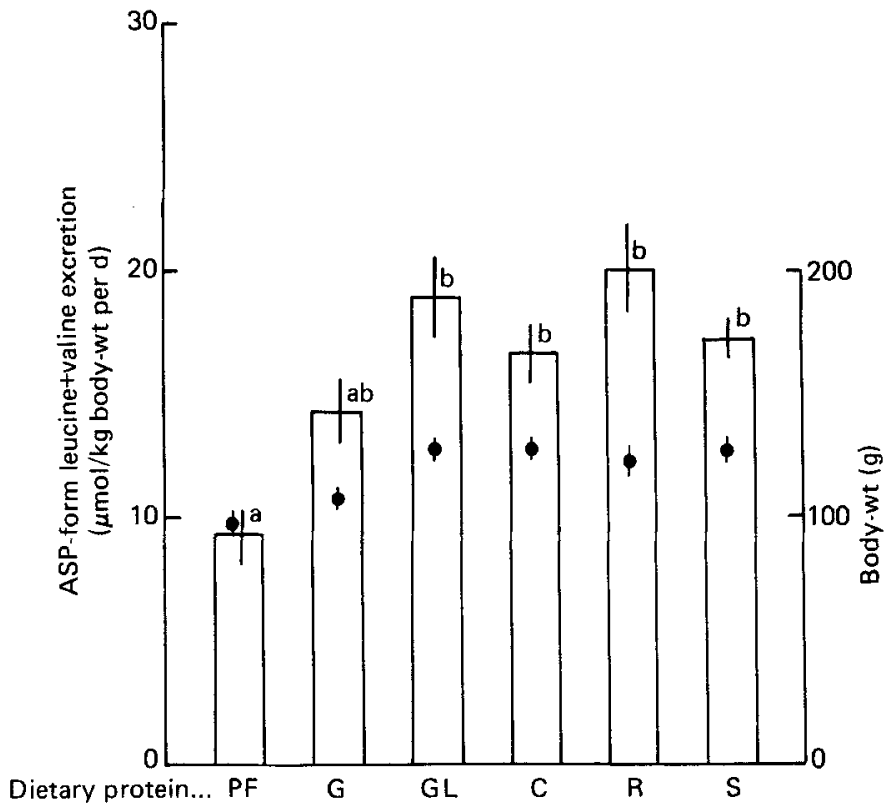

Fig. 2. Expt. 1. The rate of urinary excretion of acid-soluble peptide (ASP)-form leucine + valine in the rats fed on various protein sources: $\mathrm{C}$, casein diet; GL, wheat-gluten diet supplemented with lysine and threonine; $R$, concentrated rice-protein diet; $S$, isolated soya-bean-protein diet; $G$, wheat-gluten diet ; $\mathrm{PF}$, protein-free diet (for details, see p. 322). Values are means with their standard errors represented by vertical bars for five rats. (O), Body-weight after $7 \mathrm{~d}$ on the experimental diets (mean initial body-weight was 105 (SE 1)g, $n 30){ }^{\mathrm{a}, \mathrm{b}}$ Groups with unlike superscript letters were significantly different $(P<0.05)$ by Tukey's Q test (Snedecor \& Cochran, 1967).

there was no significant difference $(P>0.05)$ in ASP-form leucine + valine per $\mathrm{kg}$ bodyweight between the five groups of rats fed on various dietary proteins.

Fig. 3 shows that the ratio, total urinary N:ASP-form leucine + valine was lowest in the rats fed on the protein-free diet and showed a general trend in the order casein, wheat gluten supplemented with lysine and threonine, concentrated rice protein, isolated soyabean protein, gluten; although differences between adjacent diets did not always attain statistical significance. Fig. 3 also shows the efficiency of dietary protein- $\mathrm{N}$ retention calculated from this experiment. The ratio, total urinary $\mathrm{N}$ : ASP-form leucine + valine increased as the efficiency of dietary protein- $\mathrm{N}$ retention decreased. The regression equation was $Y=-1 \cdot 26 X+140$, where $X$ is the efficiency of dietary protein- $\mathrm{N}$ retention and $Y$ is the ratio, $\mathrm{N}$ : ASP-form leucine + valine. The standard deviation from the regression was $10 \cdot 6$ and the standard deviation of the regression coefficient was 0.20 . The regression coefficient was significant $(P<0 \cdot 01)$.

\section{Expt 2}

Fig. 4(c) shows the rate of excretion of ASP, together with that of total $\mathrm{N}$ and $N^{\top}$ methylhistidine, in the rats fed on graded levels of dietary casein. As shown in Fig. 4, the excretion rate of ASP-form leucine + valine gradually increased as the $\mathrm{N}$ intake increased. The excretion of $N^{\top}$-methylhistidine did not change significantly when rats received more than $170 \mathrm{mg} \mathrm{N} / \mathrm{d}(60 \mathrm{~g}$ casein $/ \mathrm{kg}$ diet $)$. On the contrary, the $\mathrm{N}$ excretion increased markedly when rats were fed on diets containing more than $180 \mathrm{~g}$ casein $/ \mathrm{kg}$.

Fig. 4(a) shows the ratio, total $\mathrm{N}$ : ASP-form leucine + valine as a function of $\mathrm{N}$ intake. 


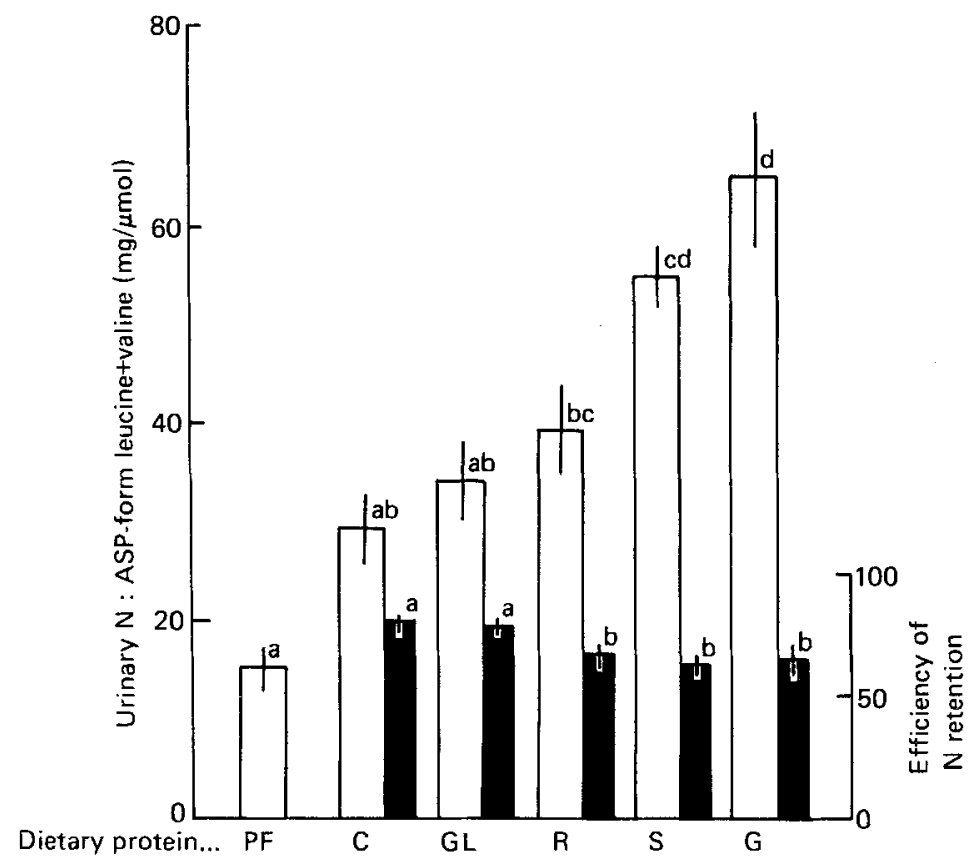

Fig. 3. Expt. 1. Urinary nitrogen :acid-soluble peptide (ASP)-form leucine + valine in rats fed on various protein sources: $C$, casein diet; GL, wheat-gluten diet supplemented with lysine and threonine; $R$, concentrated rice-protein diet; S, isolated soya-bean-protein diet; $G$, wheat-gluten diet; PF, protein-free diet (for details, see p. 322). ( $\square$ ), Urinary N : ASP-form leucine + valine; ( $)$, efficiency of retention of the dietary proteins. Values are means with their standard errors represented by vertical bars for five rats. ${ }^{a-d}$ Values with unlike superscript letters were significantly different $(P<0.05)$ by Tukey's $\mathrm{Q}$ test (Snedecor \& Cochran, 1967).

The ratio did not change significantly when the rats were fed on diets containing 0,60 or $120 \mathrm{~g}$ casein $/ \mathrm{kg}$. However, the ratio was much higher for rats fed on diets containing 180 and $240 \mathrm{~g}$ casein $/ \mathrm{kg}$.

Fig. 4(b) shows values for ASP-form leucine + valine per kg body-weight, indicating that rats fed on the protein-free diet had a lower ASP excretion than those fed on protein diets. These results suggest that the rate of urinary excretion of ASP has potential as a simple index of protein nutritional status.

\section{Expt 3}

Fig. 5 shows the effects of a lysine- or tryptophan-deficient diet on the urinary ratio, $\mathrm{N}$ :ASP-form leucine + valine. Supplementation with excess amounts of dietary lysine or tryptophan resulted in minor changes in the ratio, but depletion of these amino acids from the complete amino acid mixture resulted in a very high value for $\mathrm{N}$ :ASP-form leucine + valine which, when compared with results shown in Figs 3 and 4, could suggest wastage of dietary $\mathrm{N}$. On the other hand, the small but significant decrease in the ratio, $\mathrm{N}$ : ASP-form leucine + valine obtained by addition of excess lysine to the control amino acid diet (lysine-excess group) might suggest that the lysine requirement as recommended by the National Research Council (1978) is lower than the actual requirement if it is based on $\mathrm{N}$ efficiency. 

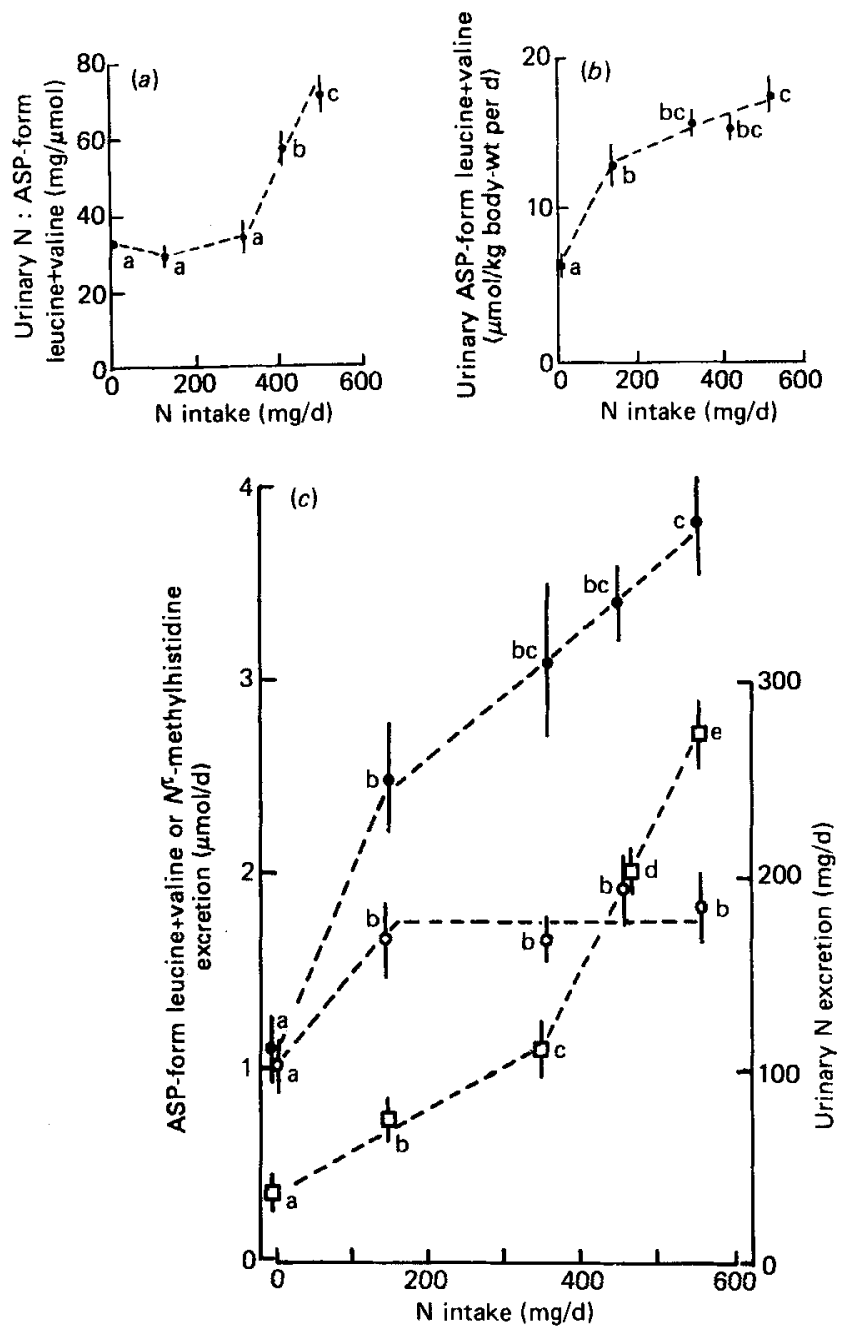

Fig. 4. Expt 2. The rate of excretion of acid-soluble peptide (ASP)-form leucine + valine, total nitrogen and $N^{\top}$-methylhistidine into urine in the rats fed on graded levels of casein in the diets (for details, see p. 322). Values are means with their standard errors represented by vertical bars for five rats. (a) N:ASPform leucine +valine $(\mathrm{mg} / \mu \mathrm{mol})$; (b) ASP-form leucine + valine ( $\mu \mathrm{mol} / \mathrm{kg}$ body-weight); (c) (O), excretion of ASP-form leucine + valine $(\mu \mathrm{mol} / \mathrm{d}) ;(O)$, excretion of $N^{\top}$-methylhistidine $(\mu \mathrm{mol} / \mathrm{d}) ;(\square)$, excretion of total $\mathrm{N}(\mathrm{mg} / \mathrm{d})$. ${ }^{a-e}$ Values with unlike superscript letters were significantly different $(P<0.05)$ by Tukey's $Q$ test (Snedecor $\&$ Cochran, 1967).

\section{Expt 4}

Fig. 6 shows that the excretion of ASP-form leucine + valine per $\mathrm{kg}$ body-weight decreased as the rats grew and increased later. The rats fed on the diet with $240 \mathrm{~g}$ casein $/ \mathrm{kg}$ excreted more ASP-form leucine + valine into the urine than the rats fed on the $120 \mathrm{~g}$ casein $/ \mathrm{kg}$ diet, when the rats were 5 weeks old (Table 2). Although there was little evidence of differences between the two dietary groups during early maturity, the excretion rate of the $240 \mathrm{~g}$ casein $/ \mathrm{kg}$ diet group substantially exceeded that of the $120 \mathrm{~g}$ casein $/ \mathrm{kg}$ diet group for rats of 9 months of age and older. The increase in excretion was found to be accelerated (at 


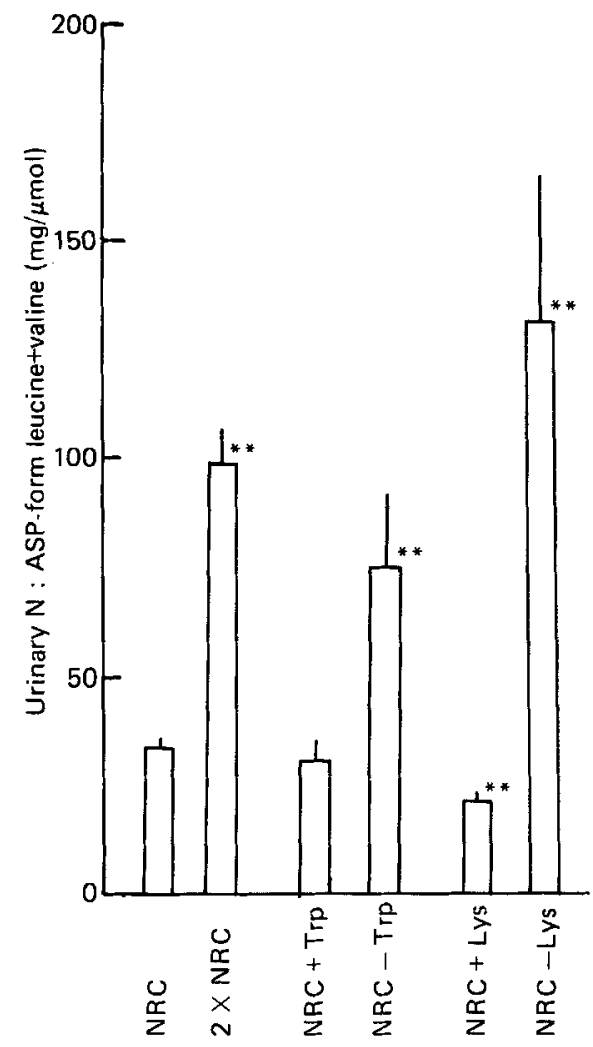

Fig. 5. Expt 3. The effect of lysine or tryptophan deficiency or excess on the ratio, urinary nitrogen: acidsoluble peptide (ASP)-form leucine + valine. Values are means with their standard errors represented by vertical bars for five rats. NRC, amino acid control diet formulated according to the recommendations of the National Research Council (1978); NRC + Lys, NRC + Trp, lysine or tryptophan respectively was added at twice the level used in the NRC diet; NRC-Lys, NRC-Trp, lysine or tryptophan respectively was omitted from the NRC diet; $2 \times \mathrm{NRC}$, twice the levels of the amino acids in the NRC diet were added to the diet. ** Mean values were significantly different from those for NRC dietary group $(P<0 \cdot 01)$ by Student's $t$ test. Other values were not significant.

about 1 year old) in the rats fed on the high-protein diet compared with the other group of rats.

However, the pattern of changes in urinary excretion of $N^{T}$-methylhistidine during growth, maturation and senescence was different from that of ASP-form leucine + valine (Fig. 7). Excretion of ASP-form proline decreased greatly as rats grew older and 30-weekold rats excreted approximately one-eighth of the amount of ASP-form proline excreted by 5 -week-old rats fed on the high-protein diet $(240 \mathrm{~g} / \mathrm{kg})$ and one-fifth of that of rats fed on the normal-protein diet $(120 \mathrm{~g} / \mathrm{kg})$.

\section{Expt 5}

Fig. 8 shows the excretion of labelled urinary ASP after injection of labelled amino acids into rats. On the 1st day after the injection of labelled amino acids, rats excreted the highest amount of ASP-form radioactivity in both $\left[{ }^{3} \mathrm{H}\right]$ valine and $\left[{ }^{14} \mathrm{C}\right]$ proline. These results suggest that a large proportion of urinary ASP is rapidly labelled and excreted in the urine within $24 \mathrm{~h}$. Quantitatively, the radioactivity excreted as ASP within $24 \mathrm{~h}$ of the injection 


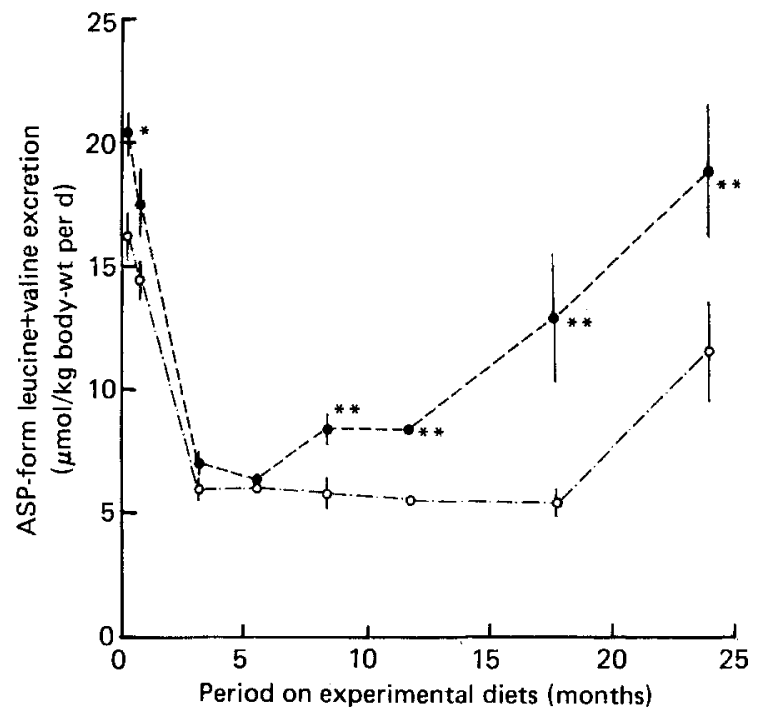

Fig. 6. Expt. 4. Changes in the rate of the urinary excretion of acid-soluble peptide (ASP)-form leucine + valine in rats fed on diets containing $120(\mathrm{O})$ or $240(O) \mathrm{g}$ casein $/ \mathrm{kg}$ diet. Values are means with their standard errors represented by vertical bars. Differences between the two dietary groups were significantly different $\left({ }^{*} P<0.05,{ }^{* *} P<0.01\right)$ by Student's $t$ test.

Table 2. The effect of casein content of a diet fed to young rats on urinary excretion of $A S P$-form leucine + valine and ASP-form proline

(Mean values with their standard errors. Male Wistar weanling rats (initial body-weight $36 \mathrm{~g}$ ) were fed on diets containing $120 \mathrm{~g}$ casein $/ \mathrm{kg}(120 \mathrm{C})$ or $240 \mathrm{~g}$ casein $/ \mathrm{kg}(240 \mathrm{C})$ for I week (five rats for each group). Urine samples were collected for $2 \mathrm{~d}$. The final body-weights (BW) were 68.1 and 64.7 for $120 \mathrm{C}$ and $240 \mathrm{C}$ respectively)

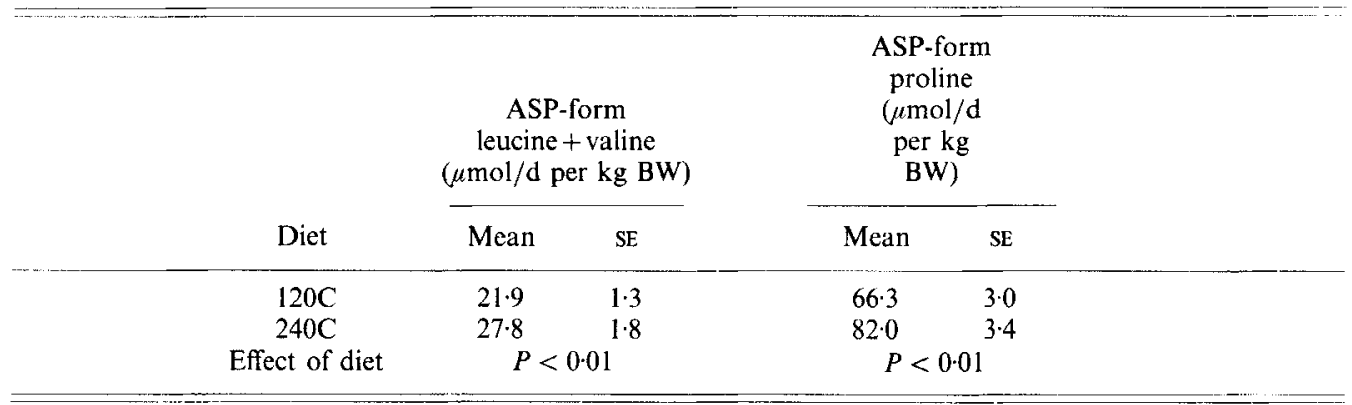

of labelled amino acid represented almost half the total radioactivity excreted as ASP during the $9 \mathrm{~d}$ after injection. The remainder is excreted more slowly with an apparent halflife of $3.8 \mathrm{~d}$ in the case of valine and $4.0 \mathrm{~d}$ in the case of proline. This conclusion was derived by fitting the logarithm of values to the linear regression, assuming that the degradation of body proteins (which is presumed to produce ASP) follows first-order reaction kinetics. The regression equations were: $Y=-0.080 X+3.4$ (half-life $3.8 \mathrm{~d}$ ) and $Y=-0.075 X+3.0$ (half-life $4.0 \mathrm{~d}$ ), for $\left[{ }^{3} \mathrm{H}\right]$ valine and $\left[{ }^{14} \mathrm{C}\right]$ proline respectively, where $X$ is time interval after injection (d) and $Y$ is the logarithm of radioactivity excreted into urine as ASP within $1 \mathrm{~d}$. Standard deviations from the regressions were 0.070 and 0.077 , and standard deviations of the regression coefficients were 0.011 and 0.012 for $\left[{ }^{3} \mathrm{H}\right]$ valine and $\left[{ }^{14} \mathrm{C}\right]$ proline respectively. 


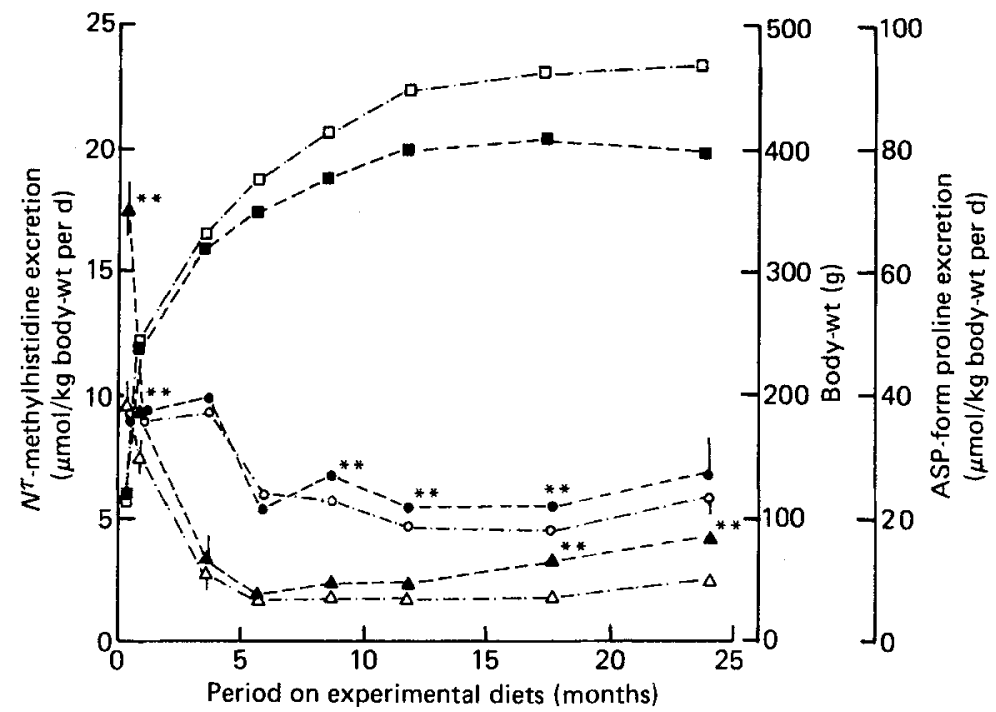

Fig. 7. Expt. 4. Changes in the rate of urinary excretion of $N^{\top}$-methylhistidine and acid-soluble peptide (ASP)-form proline in the rats fed on diets containing 120 or $240 \mathrm{~g}$ casein $/ \mathrm{kg}$ diet. (O), $N^{\top}$ methylhistidine in rats fed on $120 \mathrm{~g}$ casein $/ \mathrm{kg}$ diet $(120 \mathrm{C}$ diet $) ;(\bigcirc), N^{\top}$-methylhistidine in rats fed on $240 \mathrm{~g}$ casein $/ \mathrm{kg}$ diet ( $240 \mathrm{C}$ diet); $(\square)$, body-weight of rats fed on $120 \mathrm{C}$ diet; ( $\mathbf{O}$ ), body-weight of rats fed on $240 \mathrm{C}$ diet; $(\triangle)$. ASP-form proline in rats fed on 120C diet; $(\boldsymbol{\Delta})$, ASP-form proline in rats fed on $240 \mathrm{C}$ diet. Values are means with their standard errors represented by vertical bars; where no vertical bars are shown standard errors were within the range of the points. The differences between the two dietary groups were significant $\left({ }^{* *} P<0.01\right)$ by Student's $t$ test. The result of statistical analyses of bodyweight values is not shown.

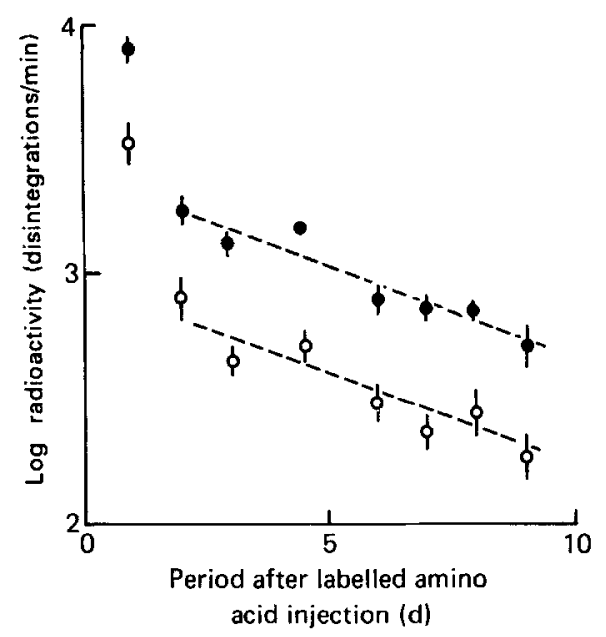

Fig. 8. Expt. 5. Excretion of labelled acid-soluble peptide (ASP) into urine after intraperitoneal injection of $\left[{ }^{3} \mathrm{H}\right]$ valine (O) or $\left[{ }^{14} \mathrm{C}\right]$ proline $(\mathrm{O})$ (for experimental details, see p. 323). Values are means with their standard errors represented by vertical bars for five rats. 
The excretion of labelled free amino acids was also biphasic both in valine and proline (values not shown). Almost $64 \%$ of the total radioactivity excreted in the urine during $9 \mathrm{~d}$ was excreted on the 1st day in the case of free valine and $53 \%$ in the case of free proline. The values for labelled free proline after $2 \mathrm{~d}$ were not as accurate because of the small amounts of labelled free proline excreted in the urine after $2 \mathrm{~d}$.

The results obtained in the present experiment suggest that the origin of urinary ASP is metabolically heterogeneous.

\section{DISCUSSION}

In the present experiments, it was shown that the rate of urinary excretion of ASP is affected by the quantity and quality of dietary proteins. When the dietary casein content was below the recommended (National Research Council, 1978) requirement (i.e. within the region of efficient utilization of dietary proteins), the excretion of ASP paralleled the total urinary excretion of $\mathrm{N}$ and the ratio, $\mathrm{N}$ : ASP-form leucine + valine was constant. However, when the dietary protein content was increased above the recommended requirement $(120 \mathrm{~g} / \mathrm{kg}$ diet $)$, the ratio, N:ASP-form leucine + valine greatly increased (Fig. $4(a))$. The ratio was low when rats were fed on a complete amino acid mixture, but was very high when a lysine- or tryptophan-deficient amino acid mixture was given (Fig. 5). This finding suggests that the ratio, N:ASP-form leucine + valine could be employed as a simple index of the efficiency of dietary protein-N utilization. If $\mathrm{N}$ : ASP-form leucine + valine is high, impaired efficiency of dietary protein- $\mathrm{N}$ utilization will be suspected. This means that the ratio is useful for the assessment of the protein or amino acid requirements of man and animals. Furthermore, this method will also be useful to assess the nutritive value of new dietary proteins prepared by food processing.

When protein nutritional status is assessed, the rate of whole-body protein synthesis or degradation is also of major concern, as well as the efficiency of dietary protein- $\mathrm{N}$ utilization. Urinary excretion of ASP is probably also useful for the assessment of the rate of whole-body protein degradation. If the excretion of ASP-form leucine + valine per unit body-weight (not the ratio, N: ASP-form leucine + valine) is lower in some patients than it is in normal subjects, a lower degradation rate of body protein will be suspected (Figs 2 and $4(b))$ and, if it is higher, enhanced degradation will be suspected. Increased excretion of ASP has been observed in diabetic rats (Noguchi et al. 1982).

There are many people whose protein nutritional status should be assessed, e.g. children suffering from protein-energy malnutrition and patients receiving total parenteral nutrition. In many of these cases, $\mathrm{N}$-balance studies to assess the protein nutritional status are too laborious or sometimes impossible to apply to hundreds of people. As pointed out by Harper (1976), Bodwell (1977) and the Food and Agriculture Organization/World Health Organization/United Nations University (1985), 'more rapid and less costly evaluation procedures are needed'. The present suggested method is simpler and may be applicable to numbers of children or patients. In particular, the difference in the pattern of excretion of urinary ASP (or ASP-form leucine + valine) from those of $N^{T}$-methylhistidine or total $\mathrm{N}$ as a function of dietary protein level (Fig. 4(c)), or growth stage (Fig. 6), suggests that the rate of excretion of urinary ASP could be employed as an index of protein metabolism.

The previously-described method for determining ASP-form amino acids after separating ASP from free amino acids by $\mathrm{Cu}$-Sephadex chromatography (Noguchi $e t$ al. 1982) was replaced by the present method, because the new method was thought to be easier for practical applications. Although the present method is simpler than N-balance studies, it is still not suitable in every case. The following improvements may be practical. First, determination of ASP-form amino acids could possibly be replaced by determination of 
total amino acids, except when amino aciduria is suspected. The reason is that the contribution of free amino acids is relatively small and not as variable in many amino acids (Table 1). Second, determination of some specific amino acids without using an amino acid analyser will bring about wider use of the present method. The use of total $\mathrm{N}$ excretion could be replaced successfully by that of urea- $\mathrm{N}$. The present authors are examining these possibilities.

Intravenously injected exogenous peptides are usually degraded very quickly in the body, with only low levels excreted in the urine (for review, see Fürst, 1985). The kidney could be responsible for the degradation of the peptides in the plasma (aminopeptidases in plasma are also presumed to be responsible for the degradation). Thus, in the case of renal failure, dysfunction in the degradation of peptides and impairment of reabsorption of the undigested peptides is possible, and may exist also for endogenous peptides produced in many organs in the body. An increase in urinary excretion of peptides will result, independent of the rate of production of endogenous peptides. When the rate of urinary excretion of ASP-form amino acids is employed for the assessment of protein nutritional status, renal function should be examined carefully. Alternatively, enhanced excretion of urinary ASP could result from a defect in the degradation system for small peptides. Indeed, rats excreted increased amounts of urinary peptides when they were injected with an inhibitor of leucine aminopeptidase (EC 3.4.1.1), bestatin (Noguchi et al. 1983; Takahashi et al. 1987). However, in this instance, an unusual excretion rate of peptides will be observed independent of physiological conditions of animals.

Another factor which affects the urinary excretion of ASP-form leucine + valine was found to be the age of the animals. Older rats excreted more ASP-form leucine + valine than young adult rats. This marked increase in excretion was not observed for ASP-form proline or $N^{\top}$-methylhistidine, suggesting that the increase was not due to renal failure. Initially the increased excretion was more rapid in the rats fed on the excess-protein diet than in those given the recommended level of protein (National Research Council, 1978). If the increased excretion rate of ASP in the older rats is related to the progress of senescence, excess protein intake should be carefully avoided in older animals. In the present experiments, we used rats at the rapidly growing stage to examine nutritional factors affecting urinary excretion of ASP. It will be very important to repeat the experiments using old rats. At present there is a lack of information about the turnover rate of whole-body protein in old rats. Waterlow et al. (1978a) showed that the rate of total protein synthesis increases by approximately $40 \%$ in 700 -d-old rats compared with 330 -d-old rats. Goldspink \& Kelly (1984) reported that the calculated rate of breakdown of whole-body protein decreased as rats grew older. The minimum protein intake of the rats was $210 \mathrm{~g} / \mathrm{kg}$ diet, which was close to our $240 \mathrm{~g} / \mathrm{kg}$ diet. They also reported that the calculated rate of breakdown of liver protein increased slightly. In another report (Lewis et al. 1985), the same group of investigators showed an increase in the calculated rate of whole-body protein breakdown in older rats. It seems to be very important to elucidate whether whole-body protein synthesis or degradation increases or decreases with age in order to estimate the protein requirement for elderly people. From this standpoint, it will be very important to compare the variables measured by Waterlow et al. (1978a), Goldspink \& Kelly (1984) and Lewis et al. (1985) with ours at the same time in the same animals. However the increase in the excretion of ASP-form leucine + valine in older animals is another characteristic of this index which differs from $N^{\top}$-methylhistidine or ASP-form proline.

It is probable that urinary ASP are the degradation products of body proteins, including collagen. The findings of Ansorge \& Hanson (1967), showing that a high proportion of urinary peptides are proline- or hydroxyproline-containing peptides, i.e. the degradation products of collagen, favour this assumption. However, the origin of ASP containing 
amino acids other than proline, hydroxyproline or glycine, or at least some of them, may be different from that of collagen, because the ratio, ASP-form proline (or hydroxyproline or glycine): ASP-form leucine changed as rats grew older (at the same growth stage, the ratio was affected little by dietary protein level or the origin of dietary proteins). ASP consist of many kinds of peptides (Takahashi et al. 1987); quantitatively, a high proportion of ASP are derived from collagen. However, the present results suggest that the remaining ASP may be useful for the assessment of protein nutritional status.

The biphasic nature of the excretion of urinary radioactive peptides after injection of radioactive amino acids shows that ASP consists of metabolically heterogeneous components. From the 2 nd day, the decrease in excretion of labelled ASP followed firstorder kinetics. Millward \& Bates (1983) showed a similar pattern of excretion of radioactive $N^{\tau}$-methylhistidine during $10 \mathrm{~d}$ after injection of $\left[{ }^{14} \mathrm{C}\right]$ methionine; the half-life (during the first few days) was calculated to be approximately $3 \mathrm{~d}$. In the present investigations, the half-life of the radioactivity of ASP-form valine after $2 \mathrm{~d}$ was $3.8 \mathrm{~d}$ and $4.0 \mathrm{~d}$ for ASP-form proline. The half-life reported by Millward \& Bates (1983) for $N^{r}$-methylhistidine and halflives in the present experiments for ASP-form valine or proline are very close. $N^{\top}$ Methylhistidine has been assumed to be released as a degradation product of tissue proteins which contain this amino acid, i.e. actin, myosin and some other proteins. The close relation in half-life between ASP and $N^{\tau}$-methylhistidine suggests that the excretion of ASP reflects some similar metabolic events to that related to the excretion of $N^{\top}$-methylhistidine (presumably the degradation of some body proteins).

In our previous paper (Noguchi et al. 1982), we discussed the possible relation between ASP excretion and endogenous urinary $N(E U N)$. EUN is defined as the minimum urinary $\mathrm{N}$ excreted by protein-deficient animals. This concept was examined in detail by Allison (1964), Mitchell (1962), and recently by the Food and Agriculture Organization/World Health Organization/United Nations University (1985). Mitchell (1962) showed that EUN is proportional to metabolic body size (body-weight ${ }^{0.75}$ ). This concept of EUN is still important and useful in protein nutrition, for example, in the calculation of net protein utilization. EUN consists of many kinds of nitrogenous compounds, e.g. urea, creatinine, uric acid, peptides, ammonia, hippuric acid, etc. So, EUN is not directly related to the rate of some specific reaction(s) within the body. However, the rate of excretion of EUN gives valuable information about the protein metabolism of animals. The excretion of ASP-form amino acids shares some common characteristics with the excretion of EUN. The rate of excretion of ASP-form amino acids was proportional to metabolic body size, as shown in our previous paper (Noguchi et al. 1982), when the growth stage and nutritional status of the animals were similar. The fractional synthesis rate of whole-body proteins is also known to be proportional to metabolic body size (Waterlow \& Jackson, 1981). It is very interesting that fractional synthesis rate of whole-body proteins, the rate of excretion of EUN and the rate of excretion of ASP-form amino acids are proportional to metabolic body size. If the rate of excretion of ASP-form amino acids is proportional to the rate of EUN excretion or the fractional synthesis rate of whole-body protein, determination of the rate of excretion of urinary ASP will give useful information about the status of protein turnover within the body.

Careful examination of the amino acid composition of ASP may also contribute to the elucidation of some hereditary disorders. It has been demonstrated that proline-containing peptides are specifically excreted into urine in prolidase $(E C$ 3.4.13.9) deficiency (Goodman et al. 1968). This finding also indicates the diagnostic importance of the analysis of urinary peptides.

Waterlow et al. (1978b) pointed out the importance of the estimation of the rate of synthesis or degradation, or both, of body proteins. Information about the rate of synthesis 
or degradation, or both, of body proteins would be useful in the assessment of the metabolic status of people suffering from protein-energy malnutrition or other nutritional deficiencies, and in the determination of the status of hundreds of patients suffering from degenerative or progressive clinical diseases. In the field of basic science, it is possible to employ radioisotopes or stable isotopes for the estimation of synthesis or degradation rate of body proteins. However, it is very difficult to apply the methods of turnover studies to hundreds of children or patients because of cost, safety in the case of radioisotopes, and labour costs. It is necessary to find reliable indices of the rate of synthesis and degradation of body proteins for the preliminary screening of patients for further examinations. From this standpoint, the method of measuring urinary $N^{\top}$-methylhistidine is presumed to be a good one (Ballard \& Tomas, 1983), although sometimes it can be unreliable (Rennie et al. 1982; Rennie \& Millward, 1983). The present method of measuring ASP is another proposed means of assessing the status of degradation of some body proteins or, hopefully, of whole-body proteins. However, the origin of urinary ASP should be carefully identified before it is concluded that urinary ASP can be employed as a useful index of body-protein degradation.

The authors acknowledge with thanks Dr M. C. Nesheim, Division of Nutritional Sciences, Cornell University and Dr Ryuhei Funabiki, Tokyo Noko University, for their helpful advice and discussions. The concentrated rice protein was kindly donated by Professor Y. Morita, Kyoto University.

\section{REFERENCES}

Adams, E. \& Frank, L. (1980). Annual Review of Biochemistry 49, 1005-1061.

Allison, J. B. (1964). In Mammalian Protein Metabolism, vol. 2, pp. 41-86 [H. N. Munro and J. B. Allison, editors]. New York and London: Academic Press.

Ansorge, S., Fittkau, S. \& Hanson, H. (1961). Hoppe-Seyler's Zeitschrift für Physiologische Chemie 324, $17-31$.

Ansorge, S. \& Hanson, H. (1967). Hoppe-Seyler's Zeitschrift für Physiologische Chemie 348, 334-346.

Asatoor, A. M., Milne, M. D. \& Walsche, J. M. (1976). Clinical Science and Molecular Medicine 51, $369-378$.

Askenasi, R. (1975). Clinica Chimica Acta 59, 87-92.

Ballard, F. J. \& Tomas, F. M. (1983). Clinical Science 65, 209-215.

Bodwell, C. E. (1977). In Evaluation of Proteins for Humans, pp. 119-148 [C. E. Bodwell, editor]. Westport, Connecticut: Avi Publishing Co.

Food and Agriculture Organization/World Health Organization/United Nations University (1985). Energy and Protein Requirements, pp. 52-70. Geneva: WHO.

Fürst, P. (1985). Clinical Nutrition, Special Suppl. 4, 105-115.

Goldspink, D. F. \& Kelly, F. J. (1984). Biochemical Journal 217, 507-516.

Goodman, S. I., Solomons, C. C., Muschenheim, F., McIntyre, C. A., Miles, B. \& O'Brien, D. (1968). American Journal of Medicine 45, 152-159.

Hanson, H. \& Ansorge, S. (1967). Hoppe-Seyler's Zeitschrift für Physiologische Chemie 348, 347-351.

Hanson, H. \& Fittkau, S. (1958). Hoppe-Seyler's Zeitschrift für Physiologische Chemie 313, 152-165.

Harper, A. E. (1976). In Proteins in Human Nutrition, pp. 349-352. [J. W. G. Porter and B. A. Rolls, editors]. London and New York: Academic Press.

Kawakami, T. \& Shimura, K. (1974). Radioisotopes 23, 81-87.

Lewis, S. E. M., Goldspink, D. F., Phillips, J. G., Merry, B. J. \& Holehan, A. M. (1985), Experimental Gerontology 20, 253-263.

Matsuki, H., Yoshio, Y. \& Nishi, H. (1976). Agricultural and Biological Chemistry 40, 851-858.

Meilman, E., Urivetezky, M. M. \& Rapoport, C. M. (1963). Journal of Clinical Investigation 42, 40-50.

Millward, D. J. \& Bates, P. C. (1983). Biochemical Journal 214, 607-615.

Mitchell, H. H. (1962). Comparative Nutrition of Man and Domestic Animals, vol. 1, pp. 129-191. New York and London: Academic Press.

National Research Council (1978). Nutrient Requirements of Laboratory Animals, 3rd ed., p. 23, Washington, DC: National Academy of Sciences.

Noguchi, T., Okiyama, A., Naito, H., Kaneko, K. \& Koike, G. (1982). Agricultural and Biological Chemistry 46, $2821-2822$.

Noguchi, T., Sonaka, I. \& Naito, H. (1983). Agricultural and Biological Chemistry 47, 647-650. 
Prockop, D. J. \& Kivirikko, K. I. (1967). Annals of Internal Medicine 66, 1243-1266.

Rennie, M. J., Edwards, R. H. T., Millward, D. J., Wolman, S. L., Halliday, D. \& Matthews, D. E. (1982). Nature 296, $165-167$.

Rennie, M. J. \& Millward, D. J. (1983). Clinical Science 65, 217-225.

Rogers, Q. R. \& Harper, A. E. (1965). Journal of Nutrition 87, 267-273.

Skarzynski, B. \& Sarnecka-Keller, M. (1962). Advances in Clinical Chemistry 5, 107-134.

Snedecor, G. W. \& Cochran, W. G. (1967). Statistical Methods, 6th ed., pp. 271-273. Ames, Iowa: Iowa State University Press.

Szymanowicz, A., Malgras, A., Randoux, A. \& Borel, J. P. (1979). Biochimica et Biophysica Acta 576, 253-262.

Takahashi, S.-I., Kato, H., Takahashi, A., Noguchi, T. \& Naito, H. (1987). International Journal of Biochemistry 19, 401-412.

Takita, T., Miyoshi, K., Kumada, K. \& Nishi, H. (1974). Agricultural and Biological Chemistry 38, 745-753.

Waley, S. G. (1966). Advances in Protein Chemistry 21, 1-112.

Waterlow, J. C., Garlick, P. J. \& Millward, D. J. (1978a). Protein Turnover in Mammalian Tissues and in the Whole Bodv, p. 451. Amsterdam, New York, Oxford: North-Holland.

Waterlow, J. C., Garlick, P. J. \& Millward, D. J. (1978b). Protein Turnover in Mammalian Tissues and in the Whole Body, pp. 1-11. Amsterdam, New York, Oxford: North-Holland.

Waterlow, J. C. \& Jackson, A. A. (1981). In Nutrition of Man, pp. 5-10 [J. C. Waterlow, editor]. London: Churchill Livingstone. 